\title{
The role of the poultry industry on kidney and genitourinary health in Pakistan
}

\author{
Salman Imtiaz', Ashar Alam², Beena Salman
}

\begin{abstract}
Pakistan is experiencing a "double burden" of disease. Under-development is associated with illnesses like infections and nutritional deficiency, and is accompanied with diseases linked with development, such as diabetes, hypertension, cancer and chronic kidney disease. In Pakistan, renal and genitourinary diseases are an important, unaddressed health issues. Chronic kidney disease of unknown etiology (CKDu) is a recognized form of renal failure in Pakistan. A possible cause of CKDu is toxins such as arsenic, cadmium, lead and other heavy metals associated with renal and genitourinary diseases. The poultry industry is an important source of both heavy metal toxins and also mycotoxins spread in the process of farming. Of the numerous mycotoxins, zearalenone and ochratoxin are well-known for their hazardous effects on genitourinary and renal parenchyma respectively. We reviewed the literature using PubMed and Google Scholar databases for levels of these toxins in various constituents of chicken farming like chicken feed, meat, litter and human drinking water contamination in various parts of the country. We found that these toxins are in higher levels than recommended.
\end{abstract}

KEYWORDS: Kidney failure, chronic kidney disease of unknown etiology, Chicken industry, Environmental diseases, Non-communicable diseases, Genitourinary diseases.

How to cite this:

doi: https://doi.org/10.12669/pjms.36.ICON-Suppl.1718

Imtiaz S, Alam A, Salman B. The role of the poultry industry on kidney and genitourinary health in Pakistan. Pak J Med Sci. Special Supplement ICON 2020. 2020;36(1):S67-S74. doi: https://doi.org/10.12669/pjms.36.ICON-Suppl.1718

This is an Open Access article distributed under the terms of the Creative Commons Attribution License (http://creativecommons.org/licenses/by/3.0), which permits unrestricted use, distribution, and reproduction in any medium, provided the original work is properly cited.

\section{INTRODUCTION}

The global upsurge in non-communicable diseases (NCDs), including heart disease, diabetes, cancers and chronic lung diseases is such that the World Health Organization (WHO) has declared

1. Prof. Dr. Salman Imtiaz

Senior Consultant Nephrologist,

2. Dr. Ashar Alam

Senior Consultant Nephrologist and Medical Director,

3. Dr. Beena Salman,

Head of the Department of Biostatistics and Epidemiology,

Department of biostatistics and epidemiology,

Dorab Patel Post Graduate Training \& Research Center,

The Kidney Center Post Graduate Training Institute, Karachi, Pakistan.

1, 2: Department of Nephrology, The Indus Hospital Karachi, Korangi Crossing 75190, Pakistan.

Correspondence:

Prof. Dr. Salman Imtiaz,

Consultant Nephrologist, Department of Nephrology,

The Indus Hospital Karachi, Korangi crossing 75190, Pakistan.

E-mail: salman.imtiaz@tih.org.pk

* Received for Publication:

September 24, 2019

* Revision accepted for Publication: November 16, 2019 a "public health emergency." NCDs cause $60 \%$ of global mortality annually and low- and middleincome countries (LMICs) account for $80 \%$ of this loss of life. ${ }^{1}$

The environment plays an important role in this rising trend. Early exposure to environmental risk factors, such as chemicals and air pollutants, might increase NCD risk throughout life. ${ }^{2}$ Growing evidence shows environmental factors affect the increasing prevalence of chronic kidney disease (CKD), ${ }^{3}$ especially in LMICs. Direct effects on the kidney may occur via water and food contamination by industrial toxins, and indirectly through environmental invasion causing other NCDs which eventually cause renal failure. ${ }^{4}$

A recent worldwide study in 12 LMICs has reported CKD prevalence of $14.3 \%$ in the general population and $36.1 \%$ in high-risk groups. ${ }^{5}$ In Pakistan, Ashar and Farhana found overall CKD prevalence of $16.6 \%$ in the community in the cosmopolitan city of Karachi. ${ }^{6}$ CKD in Pakistan, as 
elsewhere, is mostly caused by diabetes mellitus and hypertension, followed by kidney stones, glomerulonephritis and chronic kidney disease of unknown etiology (CKDu). ${ }^{7}$ The increasing prevalence of $\mathrm{CKDu}$ in Pakistan is concerning. Multiple studies to identify a particular offending agent; to assess the affected geographical areas or explore NCD hotspots have been done. ${ }^{8}$ The incidence and prevalence of $\mathrm{CKDu}$ in Pakistani hospitals is $9.1 \%$ and $26.1 \%$ respectively. ${ }^{9,10}$ No community-based studies have been done so far.

Industrial toxins, particularly heavy metals like arsenic, cadmium, copper sulphate, lead, and various mycotoxins like zearalenone and ochratoxin are associated with renal and genitourinary diseases. ${ }^{11}$ The chicken and poultry farming may contribute to the spread of these heavy metals and mycotoxins. The poultry industry, largely unregulated and unsupervised, may therefore have a role in CKDu in Pakistan. ${ }^{12}$ In this literature review, we explored toxins in constituents of chicken farming in different parts of the country and draw links with renal dysfunction and disease.

Search strategy: A keyword search of PubMed and Google Scholar was performed using "chronic kidney disease of unknown etiology", "heavy metals and kidney disease", "mycotoxin and kidney disease", "poultry and kidney and genitourinary disease". A manual search for relevant references from relevant articles not identified by the electronic search was performed. Only studies published in English until December 2018 were included.

Poultry Industry in Pakistan: In the last decade, Pakistan has boosted the poultry industry with incentives and favorable policy decisions. Large scale investment has led to over 28,000 commercial poultry farms and $150+$ feed mills in the country. About 2,821 million tons of chicken feed are produced annually and the public consumption has increased to 834 metric ton of chicken meat per annum. ${ }^{13,14}$ However, this expanding industry, unregulated by directives and surveillance, may be rapidly producing substantial health hazards.

The effect of these health hazards includes dangerous chemical and microbiological agents. An unacceptably high heavy metal content in 'normal' chicken feed or hazardous environmental exposure to mycotoxins during feed preparation has been shown (Table-I). Chickens are vectors in spreading these toxins through meat, feed, eggs and litter or manure, either directly or indirectly by polluting water and agriculture (Fig.1). This review will focus on three such contaminants i.e. arsenic, ochratoxin and zeralenone, which are important in causing kidney and genitourinary diseases.

\section{ARSENIC:}

a) Mode of spread: Arsenic occurs naturally in both organic and inorganic forms. Organic arsenic

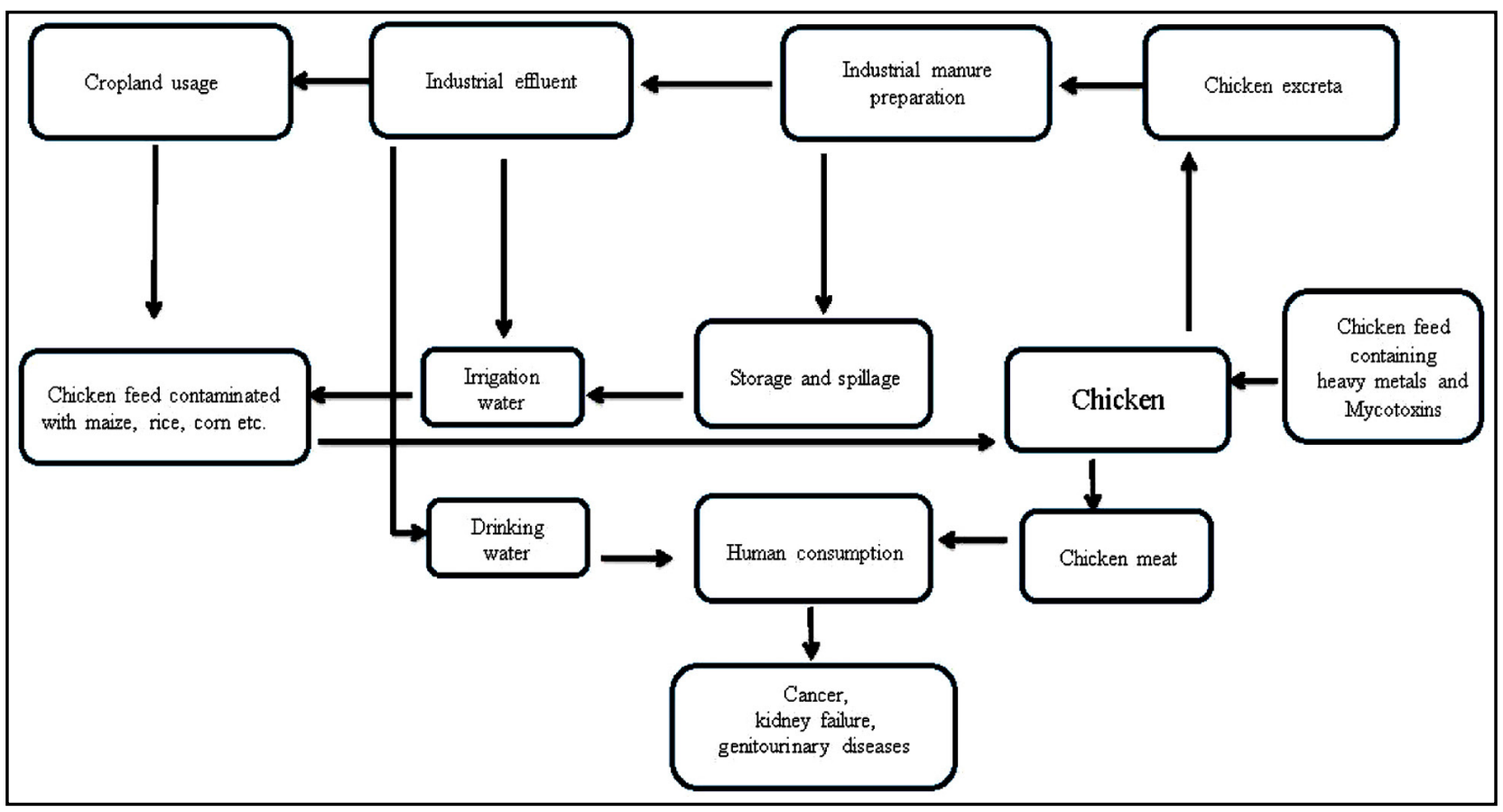

Fig.1: Schematic diagram showing pollution and contamination caused by chicken feed derived from Garbarino JR, Bednar A. ${ }^{17}$ 
Table-I: Potential chemical contaminants in poultry meat products.

\begin{tabular}{|c|c|c|}
\hline Contaminant & Source & Potential adverse effects \\
\hline Arsenic & $\begin{array}{l}\text { Environmental contamination. Use of Arsenic- } \\
\text { based anticoccidial agents. }\end{array}$ & $\begin{array}{l}\text { Human carcinogen - inducing primary skin } \\
\text { cancers. Nephrotoxic agent. }\end{array}$ \\
\hline Cadmium & Environmental contamination & Nephrotoxic agent \\
\hline Fluoride & $\begin{array}{l}\text { Contamination of mechanically separated } \\
\text { poultry with finely powdered bone. }\end{array}$ & Dental fluorosis \\
\hline Lead & $\begin{array}{l}\text { Environmental contaminant. Contamination of } \\
\text { wild crafted birds such as the Magpie Goose. }\end{array}$ & $\begin{array}{l}\text { Human neurodevelopmental toxin with } \\
\text { children being particularly sensitive }\end{array}$ \\
\hline Mercury & $\begin{array}{l}\text { Contamination of poultry fishmeal starter } \\
\text { rations. Contamination of wild crafted birds } \\
\text { such as the Mutton bird. }\end{array}$ & $\begin{array}{l}\text { Human neurotoxin - developing foetus } \\
\text { particularly sensitive }\end{array}$ \\
\hline Selenium & $\begin{array}{l}\text { Contamination of poultry fishmeal starter } \\
\text { rations. }\end{array}$ & Adverse effects on nervous system. \\
\hline $\begin{array}{l}\text { Polychlorinated } \\
\text { biphenyls }\end{array}$ & Environmental contaminant. & $\begin{array}{l}\text { Potential human carcinogen. Very low } \\
\text { tolerable monthly intake. }\end{array}$ \\
\hline $\begin{array}{l}\text { Aflatoxin B1, B2, } \\
\text { G1, G2 }\end{array}$ & $\begin{array}{l}\text { Aspergillus flavus, and A. parasiticus } \\
\text { contamination of corn, peanuts and other feed } \\
\text { ingredients }\end{array}$ & Aflatoxin B1 - potential human carcinogen \\
\hline $\begin{array}{l}\text { Trichothecenes } \\
\text { T-2 and HT-2 toxin } \\
\text { Deoxynivalenol } \\
\text { (DON) } \\
\text { Vomitoxin }\end{array}$ & $\begin{array}{l}\text { Fusarium graminearum, F. crookwellense and } \\
\text { F. culmorum contamination of wheat, barley } \\
\text { and corn }\end{array}$ & Acute food poisoning \\
\hline Zearalenone & $\begin{array}{l}\text { Fusarium graminearum, F. crookwellense and } \\
\text { F. culmorum contamination of wheat and corn }\end{array}$ & $\begin{array}{l}\text { Possible carcinogen - effects the } \\
\text { reproductive system of laboratory animals } \\
\text { and pigs }\end{array}$ \\
\hline Ochratoxin A & $\begin{array}{l}\text { Aspergillus ochraceus and Penicillium } \\
\text { verrucosum contamination of barley, wheat } \\
\text { and many other commodities }\end{array}$ & Nephrotoxin, possible human carcinogen \\
\hline Fumonisin B1 & $\begin{array}{l}\text { Fusarium moniliforme plus several less } \\
\text { common species contamination of corn }\end{array}$ & Nephrotoxin, possible human carcinogen \\
\hline
\end{tabular}

(Modified from Food Standards Australia New Zealand November 2005).

compounds have been used in the poultry industry for years. Roxarson (Ristat; 3-nitro, 4-hydroxy-3nitrobenzenearsonic acid) is an arsenic-containing component of chicken feed which promotes growth, improves efficiency of feed utilization and increases chicken meat pigmentation. It also controls spread of coccidiosis, a protozoal disease that is a major killer of farmed chickens. ${ }^{15}$ However, over $90 \%$ of arsenic is excreted unchanged in the feces. Improper decontamination of this leads to arsenic-rich manure for soil fertility. This subsequently contaminates cereals like maize, wheat and rice. ${ }^{16}$ Soil bacteria, especially Clostridium species, convert organic arsenic into dimethyl arsenic acid, monomethyl arsenic acid and inorganic arsenic compounds. These metabolites are more toxic than the original precursors found in the environment. ${ }^{17,18}$ Improper storage of chicken litter in uncovered areas also causes environmental exposure. During rainfall, arsenic leaches from storage and seeps into nearby rivers, stream, and wells. ${ }^{19}$

b) Mechanism of arsenic toxicity: The mechanism of arsenic-induced renal toxicity is well reported by Osorio and Silva in a state of the art review. ${ }^{20}$ Arsenic affects the proximal convoluted tubules by depleting intracellular glutathione stores. This activates the caspase- 3 and -9 signaling pathway, thereby increasing expression of interleukin-6 and interleukin- 8 and causes activation of the p-53 apoptotic pathway. There is increased production of Reactive Oxygen Species (ROS) and other free radicals, along with inflammation and apoptosis. Additionally, arsenic uncouples oxidative phosphorylation causing reductions in sodium, phosphate and glucose transport manifesting clinically as Fanconi syndrome causing 


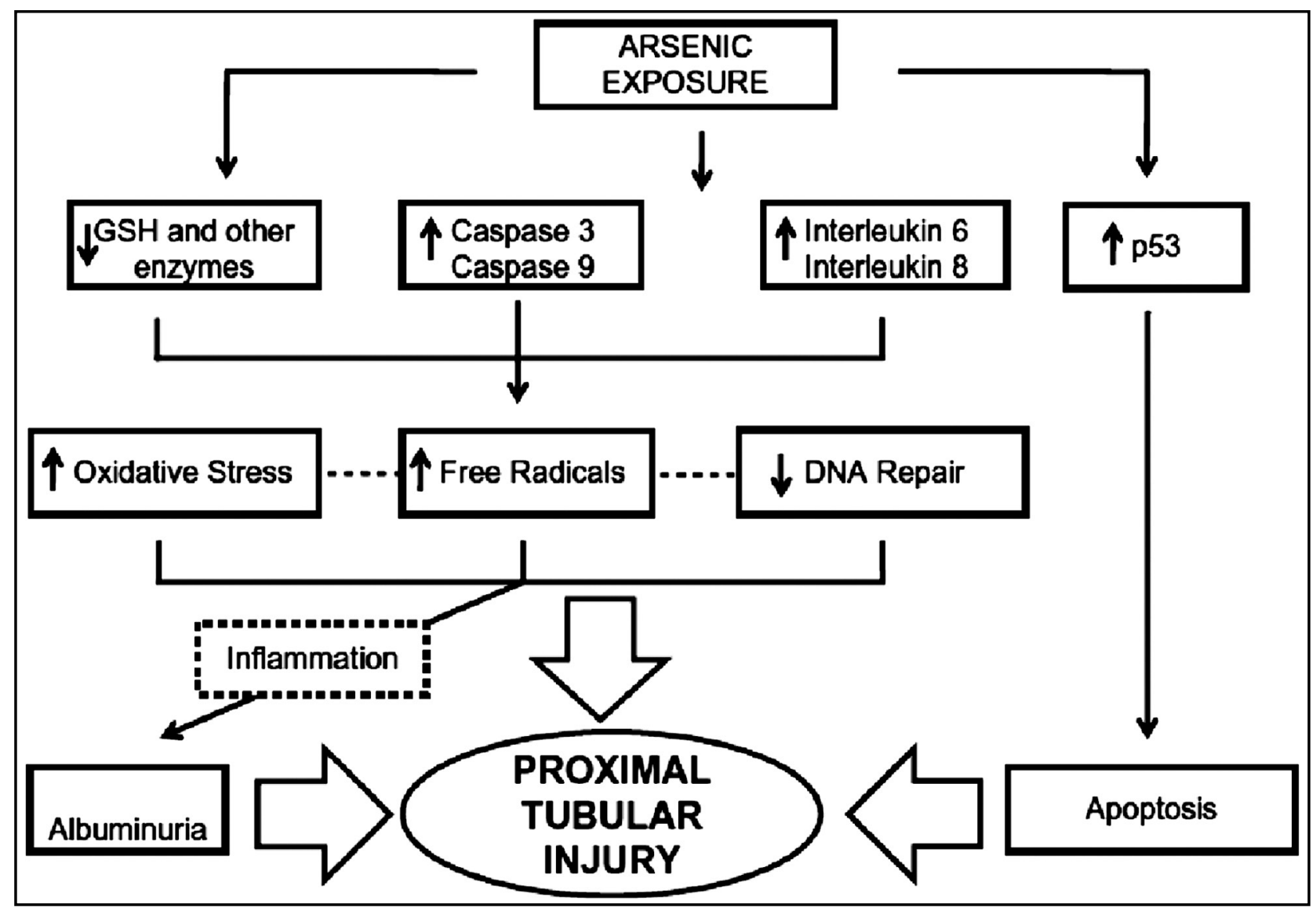

Fig.2: Mechanism of renal injury by Arsenic. ${ }^{19}$

phosphaturia, glucosuria and low-molecular weight proteinuria (Fig.2).

c) Effect of arsenic on chickensKaazi and Shah evaluated arsenic translocation from chicken feeds to different tissues of broiler chicken and their excretory products. They collected samples of chicken feed, broiler chicken meat and manure from poultry farms in Hyderabad, Pakistan. In all three types of samples, levels of arsenic exceeded international recommendations. ${ }^{21}$

To investigate if chicken feed is a source of chicken meat contamination has recently been evaluated at the Pakistan Council of Scientific and Industrial Research Laboratory. The basic constituents and additives in chicken meat, feed and droppings in broiler and organic chickens were compared. Broiler chicken were fed on commercial feeds while organic chickens were given natural grains and grit and roamed free. High levels of Roxarson were found in broiler chicken meat and their droppings, not seen in the organic chicken group..$^{22}$ In another study, Ghani and Sahito examined the levels of arsenic and lead in food items, including chicken meat. They found high arsenic concentrations, ranging above $41.3 \mathrm{ng} / \mathrm{g}$, over twice the tolerated weekly intake of $15 \mu \mathrm{g} / \mathrm{g}$ body weight. ${ }^{23}$

The impact of this contamination has been analyzed at both cellular and histological level. At the University of Agriculture, Faisalabad, Mashkoor and Khan compared the pathological effects of arsenic $(50 \mathrm{mg} / \mathrm{kg})$ on the blood and body tissues of 90-day broiler chickens. They found a significant reduction in erythrocyte count, hemoglobin and packed cell volume in arsenic treated chickens compared with controls. The liver showed gross parenchymal degeneration and necrotic changes. There were intranuclear changes like hyperchromasia, pyknosis, fragmentation and cells devoid of nucleus. The kidneys were worse affected with moderate to severe necrosis of tubular epithelial cells characterized by pyknotic nuclei and cytoplasmic vacuolation. Glomeruli were atrophied with massive lobulation and fragmentation of capillary membrane along with mononuclear infiltration and increased urinary spaces were observed. ${ }^{24}$

Although not yet evaluated in humans, malignant potential has been shown in animal studies where inorganic arsenic exposure has been 


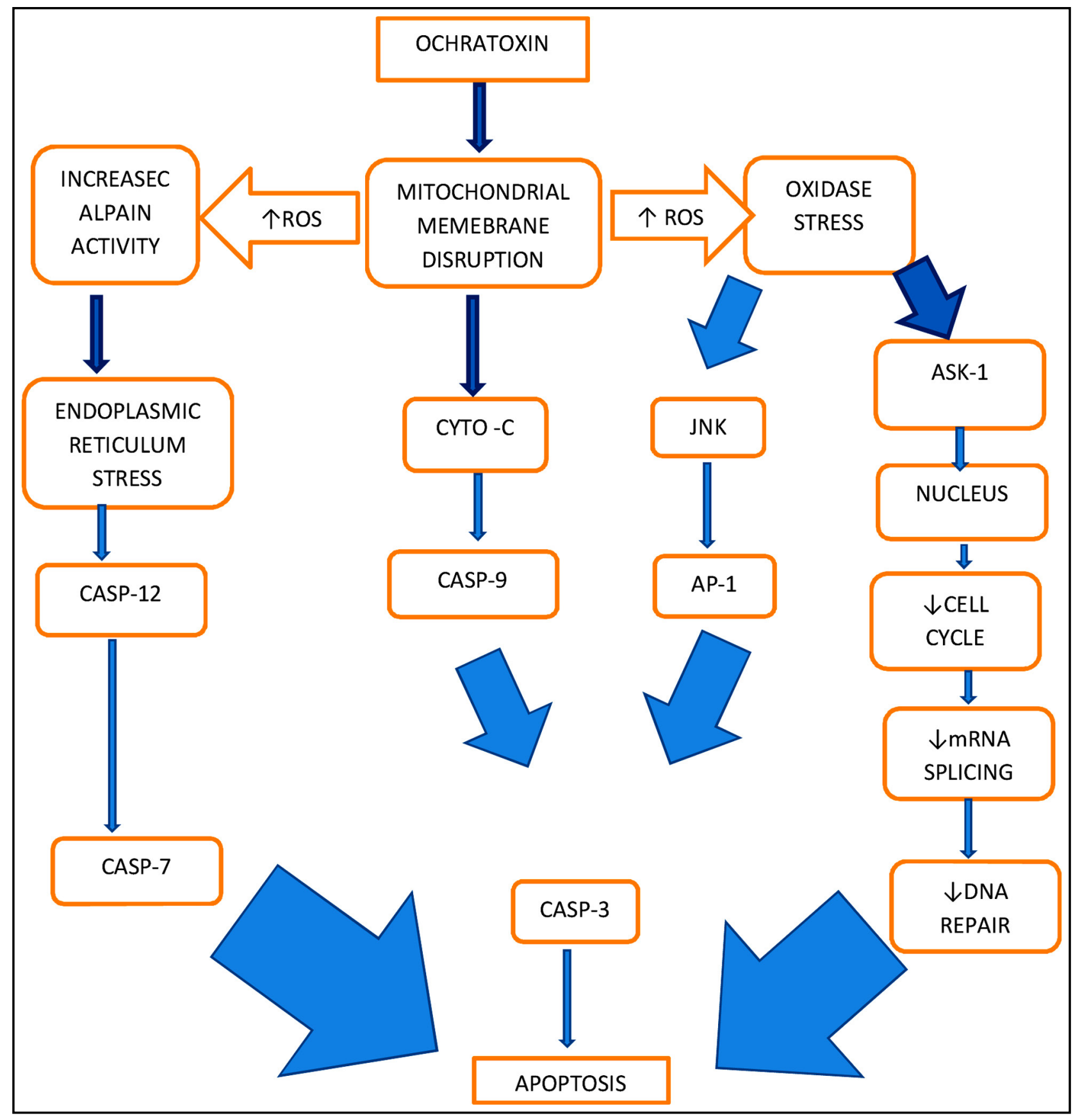

Fig.3: Mechanism of injury by Ochratoxin. Derived from mechanism of Ochratoxin Toxicity by Köszegi T and Poor M. ${ }^{43}$

associated with neoplastic transformation in both liver and kidneys. Continuous production of ROS and reactive nitrogen species (RNS) is thought to damage the thiamine nucleotides of DNA strands. ${ }^{25}$ Similarly, the mutagenic tendency of arsenic alone or in combination with copper sulphate (added to chicken feed for growth promotion, antifungal and anthelmintic effects) was compared at the University of Bahawalpur. Here, Ghaffar and Hussain observed the hematological and mutagenic effect in adult male birds fed different combinations and strengths of arsenic and copper sulphate versus a control, normal diet group. The frequency of erythrocytes with micronuclei, notched nuclei erythrocytes with nuclear remnant, blebbed nuclei, condensed nuclei and binucleated erythrocytes was significantly raised in the treated groups. ${ }^{26}$

b) Water Contamination with Arsenic: The Pakistan Council of Research in Water Resources evaluates arsenic levels regularly in the major 
Table-II: Levels of Arsenic, Ochratoxin and Zearlenone in different cities of Pakistan.

\begin{tabular}{|c|c|c|}
\hline Cities and province & $\begin{array}{rr}\text { Arsenic(ppm) } & \text { Le } \\
& \text { Reco }\end{array}$ & $\begin{array}{l}\text { evels WHO } \\
\text { ommendation } \\
<10 \text { ppm }\end{array}$ \\
\hline Gumbet, Khairpur ${ }^{53}$ & Arsenic(ppm) & 45 \\
\hline Matiari $^{53}$ & Arsenic(ppm) & $30-120$ \\
\hline Tando Mohammad Khan ${ }^{53}$ & Arsenic(ppm) & $30-100$ \\
\hline Hala $^{53}$ & Arsenic(ppm) & $40-180$ \\
\hline Nasarpur ${ }^{53}$ & Arsenic(ppm) & $13-80$ \\
\hline Nosheroferoz ${ }^{53}$ & Arsenic(ppm) & $25-60$ \\
\hline Sakrand $^{53}$ & Arsenic(ppm) & $25-50$ \\
\hline Sukkur 53 & Arsenic(ppm) & 80 \\
\hline Dadu $^{53}$ & Arsenic(ppm) & $5-60$ \\
\hline Manchar Lake ${ }^{49}$ & Arsenic(ppm) & $35-157$ \\
\hline Karachi $^{52}$ & Arsenic(ppm) & 80 \\
\hline Feroz wala ${ }^{48}$ & Arsenic(ppm) & 45 \\
\hline MuridKe $^{48}$ & Arsenic(ppm) & 40 \\
\hline Shekhopura ${ }^{48}$ & Arsenic(ppm) & 65 \\
\hline Safdarabad ${ }^{48}$ & Arsenic(ppm) & 55 \\
\hline Multan $^{54}$ & Arsenic(ppm) & $60-1000$ \\
\hline Kalan wala ${ }^{54}$ & Arsenic(ppm) & $32-1900$ \\
\hline MuzafarGarh $^{54}$ & Arsenic(ppm) & $0-400$ \\
\hline Punjab province $^{36}$ & $\begin{array}{l}\text { Ochra toxins } \\
(\mathrm{mc} / \mathrm{kg})\end{array}$ & $5-84.5$ \\
\hline Punjab province ${ }^{39}$ & Zeralenone(ppm) & 19.45 \\
\hline
\end{tabular}

cities of Pakistan. ${ }^{27}$ Persistently increasing arsenic contamination led to a national action plan initiated in 2007. A nationwide survey of drinking water was evaluated in 35 of 104 districts. Of 8712 samples, only $9 \%$ had arsenic levels meeting the WHO standard of $10 \mathrm{ppb}$. Almost $30 \%$ had levels above $10 \mathrm{ppb}$ when validated by atomic absorption spectrometry and $77 \%$ had levels above $50 \mathrm{ppb}$. The highest values were seen in the Sindh province. ${ }^{28}$

Abbas and Cheema analyzed drinking water from Sheikhupura District in Punjab. High levels of arsenic were found in hand pump samples (76.22 $\pm 20.73 \mathrm{ppb}$ ) and were only just acceptably lower in bottled water $(7.742 \pm 3.066 \mathrm{ppb}){ }^{29}$ In Sindh, Arain et al found high levels of arsenic $(96 \mu \mathrm{g} / \mathrm{l})$ in ground water and $157 \mu \mathrm{g} / \mathrm{l}$ in surface water. ${ }^{30,31}$ In Manchar Lake, the largest reservoir of fresh water in Pakistan, the levels were in the range of 35.2-158 $\mu \mathrm{g} / \mathrm{L}$, surpassing. the limit by 3-15 fold. In Jamshoro, Sindh the highest content of arsenic in surface water samples was found to be $50 \mu \mathrm{g} / 1 .{ }^{32-35}$

The poultry industry may contribute to water contamination due to unregulated dumping of chicken feed and manure in drinking water resources. Further study is required to establish these possible links through community based studies.

d) Effect of Arsenic on Human Kidney: There is evidence of the effects of arsenic on in the renal system of humans. A case report of an AfricanAmerican woman with high urea and creatinine and proximal tubular abnormalities revealed a dietary history of approximately 20 ounces of chicken, five to six times a week. Her 24-hour urine collection showed arsenic concentrations of $126 \mu \mathrm{gms}$ whilst the threshold for toxic values is $50 \mu / 24 \mathrm{hrs} .^{36}$

Hsueh et al found a dose-dependent relationship between total urinary arsenic levels and associated CKD, especially when levels were over 20.74 and creatinine levels less than $11.78 \mu \mathrm{g} / \mathrm{g}$ (OR 4.34; 95\% confidence interval, 1.94-9.69). Those with high urinary total arsenic level or with low proportion of dimethylarsinic acid had a positive association with CKD when their plasma lycopene (an antioxidant which protects against ROS) level was low. ${ }^{37}$

Exposure to arsenic concentration in drinking water more than 300 microg/L is well known to cause renal and other systemic diseases, but the effect of mild to moderate exposure (10 to 100 micrg/L) is not known. In Michigan (USA), Meliker et al investigated the relationship between moderate arsenic levels and selected disease outcomes and found a significant association between the arsenic exposure and CKD. ${ }^{38}$

Status of Mycotoxin in Pakistan: "Mycotoxins" refers to poisonous substances produced by fungi. Contamination of food commodities by mycotoxins is a significant food safety challenge ${ }^{39}$ causing a huge food wastage. Over 400 mycotoxins are recognized, from which aflatoxin, ochratoxin A (OTA), fumonisins, zearalenone (ZEA), deoxy nivalenol (DON) are important for their serious hazards on human and animal health. The mechanism of spreading and proliferation of different mycotoxins has been reviewed in detail elsewhere. ${ }^{39}$

Zearalenone: Mycoestrogen or zearalenone (ZEA) is a metabolite of Fusarium species like Fusarium graminearum, a common contaminant of cereals and animal feed worldwide. It has structural similarity with 17 beta-estradiol and action on the hypothalamus and pituitary is similar to estrogen. It is well-known for deleterious effect on the human reproductive system ${ }^{40,41}$ e.g. early onset puberty in female children. ${ }^{42,43}$ The cellular effects of ZEA are poorly understood. Lysosomes may be the primary target as lysosomal injury may precede DNA strand breakage when explored in HEK293 cells (transformed human primary embryonic kidney cells). ${ }^{44}$

When 865 poultry feeds from different parts of Pakistan were investigated, $49 \%$ were contaminated with ZEA. ${ }^{45}$ Corn in chicken feed is thought to be the major source of ZEA contamination. When 
Khatoon et al evaluated ZEA concentration in maize throughout Pakistan, they found it was significantly higher than recommended levels. ${ }^{46}$ Iqbal and Rabbani analyzed 237 Pakistani breakfast cereals and found that $53 \%$ had ZEA contamination, $8 \%$ above the European Commission upper limit of 50 ug/kg. ${ }^{47}$ Iqbal and Zia found similar results when they examined 107 chicken feed and ingredients. Samples from farmers, industries and general stores from big cities in Punjab found poultry feed to have the highest levels of ZEA. ${ }^{48}$

In the only animal study conducted using chicken meat and feed in Pakistan, Sara Ahmed at Baqai University investigated the effects on estradiol, a zearalenone metabolite, in Wister rats was seen. One group was served control feed (rat chow), another served commercially prepared chicken feed and the third was given raw commercial boneless chicken meat. Results showed the gains in weight and estradiol level were highest among the rats fed chicken meat, followed by those fed chicken feed compared with controls. ${ }^{49}$

Ochratoxin: Ochratoxins, another class of mycotoxins, are produced by Aspergillus and Penicillium species. Of three forms $\mathrm{A}, \mathrm{B}$ and $\mathrm{C}$, ochratoxin A (OTA) is most toxic. It is a powerful nephrotoxin, carcinogen, teratogen and immunetoxin $^{50}$. Poultry is recognized as a major food source contaminated with ochratoxin. ${ }^{51}$

The mechanism by which ochratoxin causes cell damage is complex. In summary, it is thought to cause inhibition of protein synthesis and energy generation, possibly via oxidative stress, DNA adduct formation with apoptosis and necrosis causing cell cycle arrest. An excellent review has been written by Koszegi and Poor ${ }^{52}$ from which a schematic mechanism is extracted for the interested reader (Fig.2).

In Pakistan, Fareed and Khan evaluated levels of ochratoxin in poultry feed. Ochratoxin contamination was seen in $63 \%$ of poultry feed ingredients and $29 \%$ of poultry feed products. ${ }^{53}$ Abid and Khatoon analyzed OTA in mixed poultry feed and their ingredients from farms and markets in Lahore. Samples were collected in three time intervals, i.e. July to October (hot and humid), November to February (winter) and March to June (moderate). The incidence of OTA-positive samples was highest in July to October (82\%), followed by March to June $(67 \%)$ and lowest during November to February (58\%). They concluded that OTA levels in poultry feed ingredients (e.g. canola, soybean and sunflower meal, maize and whole cotton seeds) were alarmingly high. Entry of mycotoxins into the poultry feed chains is irreversible. Strict regulation of feed and feed ingredients to prevent its spread in poultry is recommended..$^{54}$

\section{CONCLUSION}

Industrial pollution is an important cause of NCDs amongst which CKD has a dramatically increasing prevalence. $\mathrm{CKDu}$, common in Pakistan, may result from exposure to toxin contaminated water and food and is a potentially preventable cause. Access to quality healthcare may be poor, resulting in late presentation of end stage kidney disease. The costs of care of CKD is extremely high, as is the mortality. There is an urgent need for evaluation, monitoring and regulation of the chicken and chicken feed industry to prevent mycotoxin, arsenic and heavy metal toxicity. Further community-based studies to link these toxins to CKDu are desperately required.

Conflicts of Interest: None.

Source of funding: None.

\section{REFERENCES}

1. Lozano R, Naghavi M, Foreman K, Lim S, Shibuya K, Aboyans V, et al. Global and regional mortality from 235 causes of death for 20 age groups in 1990 and 2010: A systematic analysis for the Global Burden of Disease Study 2010. Lancet. 2012;380(9859):2095-2128. doi: 10.1016/S0140-6736(12)61728-0

2. Organization WH. Preventing noncommunicable diseases (NCDs) by reducing environmental risk factors. World Health Organization; 2017.

3. Soderland P, Lovekar S, Weiner DE, Brooks DR, Kaufman JS Chronic kidney disease associated with environmental toxins and exposures. Adv Chronic Kidney Dis. 2010;17(3):254-264. doi: 10.1053/j.ackd.2010.03.011

4. Stanifer JW, Muiru A, Jafar TH, Patel UD. Chronic kidney disease in low- and middle-income countries. Nephrol Dial Transplant. 2016;31(6):868-874. doi: 10.1093/ndt/gfv466

5. Ene-Iordache B, Perico N, Bikbov B, Carminati S, Remuzzi A, Perna A, et al. Chronic kidney disease and cardiovascular risk in six regions of the world (ISN-KDDC): a cross-sectional study. Lancet Glob Health. 2016;4(5):e307-319. doi: 10.1016/ S2214-109X(16)00071-1

6. Alam A, Amanullah F, Baig-Ansari N, Lotia-Farrukh I, Khan FS. Prevalence and risk factors of kidney disease in urban Karachi: baseline findings from a community cohort study. BMC Res Notes. 2014;7(1):179. doi: 10.1186/1756-0500-7-179

7. Imtiaz S, Salman B, Qureshi R, Drohlia MF, Ahmad A. A review of the epidemiology of chronic kidney disease in Pakistan: A global and regional perspective. Saudi J Kidney Dis Transpl. 2018;29(6):14411451.doi: 10.4103/1319-2442.248307.

8. Abraham G, Varughese S, Thandavan T, Iyengar A, Fernando E, Naqvi SA, et al. Chronic kidney disease hotspots in developing countries in South Asia. Clin Kidney J. 2016;9(1):135-141. doi: 10.1093/ckj/sfv109.

9. Salman B, Imtiaz S, Qureshi R, Dhrolia MF, Ahmad A. The Causes of Chronic Kidney Disease in Adults in a Developing Country. J Nephrol Renal Dis. 2018;01(01). doi: 10.4172/2576-3962.1000105

10. Rizvi SA, Manzoor K. Causes of chronic renal failure in pakistan: a single large center experience. Saudi J Kidney Dis Transpl. 2002;13(3):376-379.

11. Lunyera J, Smith SR. Heavy metal nephropathy: considerations for exposure analysis. Kidney Int. 2017;92(3):548-550. doi: 10.1016/j. kint.2017.04.043 
12. Lunyera J, Mohottige D, Von Isenburg M, Jeuland M, Patel UD, Stanifer JW. CKD of Uncertain Etiology: A Systematic Review. Clin J Am Soc Nephrol. 2016;11(3):379-385. doi: 10.2215/CJN.07500715

13. Hussain J, Rabbani I, Aslam S, Ahmad HA. An overview of poultry industry in Pakistan. Worlds Poult Sci J. 2015;71(4):689-700. doi: 10.1017/S0043933915002366

14. Memon NAJFJ. Poultry: Country's second-largest industry. 2012;2(6):27-30.

15. McDougald LR, Gilbert JM, Fuller L, Rotibi A, Xie M, Zhu G. How Much Does Roxarsone Contribute to Coccidiosis Control in Broilers when Used in Combination with Ionophores? J Appl Poult Res. 1992;1(2):172-179. doi: 10.1093/japr/1.2.172

16. K PM, Adak A, Blaney L. Organoarsenicals in poultry litter detection, fate, and toxicity. Environ Int. 2015;75:68-80. doi: 10.1016/j. envint.2014.10.022

17. Garbarino JR, Bednar AJ, Rutherford DW, Beyer RS, Wershaw RL. Environmental fate of roxarsone in poultry litter. I. Degradation of roxarsone during composting. Environ Sci Technol. 2003;37(8):15091514. doi: 10.1021/es026219q

18. Stolz JF, Perera E, Kilonzo B, Kail B, Crable B, Fisher E, et al. Biotransformation of 3-nitro-4-hydroxybenzene arsonic acid (roxarsone) and release of inorganic arsenic by Clostridium species. Environ Sci Technol. 2007;41(3):818-823. doi: 10.1021/es061802i

19. Jackson BP, Seaman JC, Bertsch PM. Fate of arsenic compounds in poultry litter upon land application. Chemosphere. 2006;65(11):20282034. doi: 10.1016/j.chemosphere.2006.06.065.

20. Robles-Osorio ML, Sabath-Silva E, Sabath E. Arsenicmediated nephrotoxicity. Ren Fail. 2015;37(4):542-547. doi: 10.3109/0886022X.2015.1013419

21. Gul Kazi T, Qadir Shah A, Imran Afridi H, Ali Shah N, Balal Arain M. Hazardous impact of organic arsenical compounds in chicken feed on different tissues of broiler chicken and manure. Ecotoxicol Environ Saf. 2013;87:120-123. doi: 10.1016/j.ecoenv.2012.10.012

22. Ahmad S, Rehman R, Haider S, Batool Z, Ahmed F, Ahmed SB, et al. Quantitative and qualitative assessment of additives present in broiler chicken feed and meat and their implications for human health. 2018;68(6):876-881.

23. Ghani A, Sahito A, Naeem S, Kayama F, Fatmi Z. An experimental study of arsenic and lead concentration in common food sources. Int J Comm Med Pub Health. 2018;5(9):4161. doi: 10.18203/2394-6040. ijcmph20183613

24. Mashkoor J, Khan A, Khan MZ, Abbas RZ, Saleemi MK, Mahmood FJPJAS. Arsenic induced clinico-hemato-pathological alterations in broilers and its attenuation by vitamin $\mathrm{E}$ and selenium. 2013;50:131-138.

25. Tokar EJ, Diwan BA, Waalkes MP. Renal, hepatic, pulmonary and adrenal tumors induced by prenatal inorganic arsenic followed by dimethylarsinic acid in adulthood in CD1 mice. Toxicol Lett. 2012;209(2):179-185. doi: 10.1016/j.toxlet.2011.12.016

26. Ghaffar A, Hussain R, Khan A, Abbas R, Asad MJJAPS. Clinicohematological and mutagenic changes induced by arsenic and copper sulphate in adult poultry males. 2015;25:1555-1561.

27. (PCRWR) PCORIWR, World WRfC. water quality status in pakistan Phase-i 2001-2002 2002 [Available from: http://www.pcrwr.gov. pk/publication.php?view_quality.

28. NAPAM. National Data Plan Arsenic mitigation, Pakistan Water and sanitation gateway. Ministry of Environment, Government of Pakistan. 2007-2011 [

29. Abbas M, Cheema KJJoA, Sciences P. Arsenic levels in drinking water and associated health risk in District Sheikhupura, Pakistan. 2015;25(3):719-724.

30. Arain MB, Kazi TG, Jamali MK, Afridi HI, Baig JA, Jalbani N, et al. Evaluation of physico-chemical parameters of Manchar Lake water and their comparison with other global published values. Pak J Anal Environ Chem. 2008;9(2):9.

31. Arain MB, Kazi TG, Baig JA, Jamali MK, Afridi HI, Shah AQ, et al. Determination of arsenic levels in lake water, sediment, and foodstuff from selected area of Sindh, Pakistan: estimation of daily dietary intake. Food Chem Toxicol. 2009;47(1):242-248. doi: 10.1016/j.fct.2008.11.009

32. Tariq M, Ali M, Shah ZJSE. Characteristics of industrial effluents and their possible impacts on quality of underground water. Soil Environ. 2006;25(1):64-69.

33. Saif M, Haq M, Memon KJIJoA, Biology. Heavy metals contamination through industrial effluent to irrigation water and soil in Korangi area of Karachi (Pakistan). Int J Agric Biol. 2005;4:646-648.
34. Bhatti ZA, Qureshi K, Bhatti I, Unar IN, Khuhawar MY Determination of Arsenic and Health Risk Assessment in the Ground Water of Sindh, Pakistan. Mehran Uni Res J Engineer Technol. 2017;36(4):1037-1048. doi: 10.22581/muet1982.1704.28

35. Azizullah A, Khattak MN, Richter P, Hader DP. Water pollution in Pakistan and its impact on public health-a review. Environ Int 2011;37(2):479-497. doi: 10.1016/j.envint.2010.10.007

36. Sekar A, Simon J, Taliercio J. Adult-Onset Proximal Tubule Dysfunction. Am J Kidney Dis. 2018;71(1):A12-A14. doi: 10.1053/j ajkd.2017.08.025

37. Hsueh YM, Chung CJ, Shiue HS, Chen JB, Chiang SS, Yang MH, et al Urinary arsenic species and CKD in a Taiwanese population: a casecontrol study. Am J Kidney Dis. 2009;54(5):859-870. doi: 10.1053/j. ajkd.2009.06.016

38. Meliker JR, Wahl RL, Cameron LL, Nriagu JO. Arsenic in drinking water and cerebrovascular disease, diabetes mellitus, and kidney disease in Michigan: a standardized mortality ratio analysis. Environ Health. 2007;6(1):4. doi: 10.1186/1476-069X-6-4

39. Ashiq S. Natural Occurrence of Mycotoxins in Food and Feed Pakistan Perspective. Comprehensive Reviews in Food Science and Food Safety. 2015;14(2):159-175. doi: 10.1111/1541-4337.12122.

40. Belhassen H, Jimenez-Diaz I, Arrebola JP, Ghali R, Ghorbel H, Olea $\mathrm{N}$, et al. Zearalenone and its metabolites in urine and breast cancer risk: a case-control study in Tunisia. Chemosphere. 2015;128:1-6. doi: 10.1016/j.chemosphere.2014.12.055

41. Pajewska M, Lojko M, Cendrowski K, Sawicki W, Kowalkowski T, Buszewski B, et al. The determination of zearalenone and its major metabolites in endometrial cancer tissues. Anal Bioanal Chem. 2018;410(5):1571-1582. doi: 10.1007/s00216-017-0807-7

42. Gajecka M. The effect of experimental low zearalenone intoxication on ovarian follicles in pre-pubertal bitches. Polish J Veteri Sci. 2013;16(1):45-54. doi: 10.2478/pjvs-2013-0007

43. Zatecka E, Ded L, Elzeinova F, Kubatova A, Dorosh A, Margaryan $\mathrm{H}$, et al. Effect of zearalenone on reproductive parameters and expression of selected testicular genes in mice. Reprod Toxicol. 2014;45:20-30. doi: 10.1016/j.reprotox.2014.01.003

44. Gao F, Jiang LP, Chen M, Geng CY, Yang G, Ji F, et al. Genotoxic effects induced by zearalenone in a human embryonic kidney cell line. Mutat Res. 2013;755(1):6-10. doi: 10.1016/j.mrgentox.2013.04.009

45. Hanif NQ, Naseem M, Khatoon S, Malik NJ. Prevalence of mycotoxins in poultry finished feed. J Anim Vet Adv. 2005;4(2):189-193.

46. Khatoon S, Hanif NQ, Tahira I, Sultana N, Sultana K, Ayub NJ Natural occurrence of aflatoxins, zearalenone and trichothecenes in maize grown in Pakistan. Pak J Bot.. 2012;44(1):231-236.

47. Iqbal SZ, Rabbani T, Asi MR, Jinap S. Assessment of aflatoxins, ochratoxin A and zearalenone in breakfast cereals. Food Chem. 2014;157:257-262. doi: 10.1016/j.foodchem.2014.01.129.

48. Iqbal SZ, Asi MR, Nisar S, Zia KM, Jinap S, Malik N. A Limited Survey of Aflatoxins and Zearalenone in Feed and Feed Ingredients from Pakistan. J Food Prot. 2016;79(10):1798-1801. doi: 10.4315/0362028X.JFP-16-091

49. Saara A. The effect of commercially available chicken feed and chicken meat on body weight and serum estrogen levels in female albino Wistar rats. Int J Livestock Produc. 2017;8(2):24-27. doi: 10.5897/ijlp2016.0339

50. Richard JL. Some major mycotoxins and their mycotoxicoses--an overview. Int J Food Microbiol. 2007;119(1-2):3-10. doi: 10.1016/j. ijfoodmicro.2007.07.019

51. Schiavone A, Cavallero C, Girotto L, Pozzo L, Antoniazzi S, Cavallarin L. A survey on the occurrence of ochratoxin A in feeds and sera collected in conventional and organic poultry farms in Northern Italy. Ital J Animal Sci. 2016;7(4):495-503. doi: 10.4081/ ijas.2008.495

52. Koszegi T, Poor M. Ochratoxin A: Molecular Interactions, Mechanisms of Toxicity and Prevention at the Molecular Level. Toxins (Basel). 2016;8(4):111. doi: 10.3390/toxins8040111

53. Fareed G, Khan S, Anjum M, Ahmed N. Determination of Aflatoxin and Ochratoxin in poultry feed ingredients and finished feed in humid semi-tropical environment. J Adv Veterin Animal Res. 2014;1(4):201. doi: 10.5455/javar.2014.a38

54. Abidin Z, Khatoon A, Arooj N, Hussain S, Ali S, Manzoor AW, et al. Estimation of ochratoxin A in poultry feed and its ingredients with special reference to temperature conditions. Br Poult Sci. 2017;58(3):251-255. doi: 10.1080/00071668.2017.1293797 